\title{
Yukarı Gediz Havzası Yağışlarının Meteorolojik Kuraklık Analizleri
}

\section{Meteorological Drought Analysis of Upper Gediz Basin Precipitations}

\author{
Ahmet Ali Kumanlığlu ${ }^{*} \oplus$, Okan Fıstıkoğlu 2 (1) \\ 1 Manisa Celal Bayar Üniversitesi Mühendislik Fakültesi İnșaat Mühendisliği Bölümü, Manisa, TÜRKIYE \\ ${ }^{2}$ Dokuz Eylül Üniversitesi Mühendislik Fakültesi İnşaat Mühendisliği Bölümü, İzmir, TÜRKIYE \\ Sorumlu Yazar / Corresponding Author*: ahmet.kumanlioglu@cbu.edu.tr \\ Geliş Tarihi / Received: 16.11 .2018 \\ DOI:10.21205/deufmd.2019216216 \\ Kabul Tarihi / Accepted: 23.12.2018 \\ Araștırma Makalesi/Research Article \\ Atıfșekli/How to cite: KUMANLIOĞLU, A. A., FISTIKOĞLU, O. (2019). Yukarı Gediz Havzası Yağışlarının Meteorolojik Kuraklık Analizleri.
} DEUFMD, 21(62), 509-523.

Öz

Su kaynaklarının sürdürülebilir yönetimi açısından akarsu havzalarında yaşanan kuraklıkların şiddetinin ve süresinin niceliksel olarak tanılanması oldukça büyük önem arz etmektedir. Bu amaçla, literatürde pek çok farklı indis yöntemi geliștirilmekle birlikte bunlar arasındaki standartlaştırılmış yağış indisi (SYİ) uygulamada en çok tercih edilen yöntem olmuştur. Sunulan çalışma kapsamında SYİ yöntemi kullanılarak, ülkemizin Ege Bölgesi'nde yer alan Yukarı Gediz Havzası'nda meydana gelen meteorolojik kuraklıklar incelenmiştir. Havzada yer alan Demirci, İcikler, Kula, Selendi, Gediz ve Ușak istasyonlarında 1960-2017 yılları arasında ölçülen aylık toplam yağış değerleri kullanılarak bölgenin aylık, mevsimlik ve yıllık periyotlarda meydana gelen kuraklıklarının şiddeti, süresi ve sınıfları belirlenmiştir. Çalışma sonucunda, son 58 yıllık dönem içinde özellikle kış aylarında dolayısıyla kış mevsiminde görülen kuraklıkların yıllık kuraklar üzerinde etkili olduğu ve son dönemde görülen kuraklıkların şiddet ve sürelerinde artış olduğu belirlenmiștir.

Anahtar Kelimeler: Gediz Havzası, Meteorolojik Kuraklık, Standartlaştırılmış Yağış İndeksi

\begin{abstract}
In terms of sustainable management of water resources, the quantification of the severity and duration of drought in river basins is of great importance. For this purpose, many different index methods have been developed in the literature, but the standardized precipitation index (SPI) among them has been the most preferred method in practice. In this study, meteorological droughts occurring in the Upper Gediz Basin in the Aegean Region of the country were investigated by using the SPI method. The intensity and duration of the drought in the monthly, seasonal and annual periods of the region were determined by using the monthly total precipitation values measured between the years 1960-2017 at the Demirci, İcikler, Kula, Selendi, Gediz and Ușak stations in the basin. As a result, it has been pointed out that there is an increase in the duration and the intensities of the winter droughts and winter droughts are dominant in the annual drought periods.
\end{abstract}

Keywords: Gediz Basin, Meteorological Drought, Standardized Precipitation Index 


\section{Giriş}

Yeryüzü ikliminde yaşanan tedrici değişimler yağış, sıcaklık, buharlaşma ve akış gibi pek çok hidro-meteorolojik sürecin frekans ve şiddetinde değişimlere neden olmaktadır. $\mathrm{Bu}$ değişimler neticesinde ortaya çıkan ve engellenemez bir doğal süreç olan kuraklık, su kaynaklarının sürdürülebilir yönetimi açısından planlamacılar için önemli bir sınır șart oluşturmaktadır.

Zaman boyutunda meteorolojik olarak başlayıp tarımsal ve hidrolojik kuraklık olarak üç evrede gerçekleșebilen kuraklık süreci, kısa süreli ve hafif șiddete gerçekleșebileceği gibi, uzun süreli ve şiddetli bir biçimde de meydana gelebilmektedir. Kuraklığın süresine ve şiddetine bağlı olarak, yağışlardaki azalmalara paralel, yeraltı ve yerüstü su kaynakları yanında sucul ekosistemler ve sosyo-ekonomik yaşam şartları da kuraklıktan olumsuz yönde etkilenmektedir. Bu nedenle, su kaynaklarının sürdürülebilirlik anlayışı ile planlanabilmesi için akarsu havzalarında yaşanan kuraklık süreçlerinin tip, şiddet ve süre açısından tanılanması büyük önem arz etmektedir [1-4].

Yağışın belli bir dönem içerisinde normale (ortalamaya) göre daha az seviyede düşmesi olarak tanımlanan meteorolojik kuraklık, kuraklık sürecinin başlangıcını ifade eden en önemli parametredir [5]. Meteorolojik kuraklığın şiddet ve süresinin belirlenebilmesi amacıyla standartlaştırılmış yağış indeksi normalin yüzdesi indeksi, ondalıklar indeksi, yağış anomali indeksi gibi pek çok indeks tanımlanmıștır.

$\mathrm{Bu}$ indekslerden, meteorolojik kuraklığı tanımlamada sadece yağış değerlerini kullanan standartlaştırılmış yağıș indeksi (SYİ) yöntemi dünyada sıklıkla kullanılır hale gelmiştir [6-9]. Dünya genelinde farklı kıtalardaki 10 ülkede bulunan toplam 12 bölgede gözlenmiş yağışla , farklı meteorolojik kuraklı indekslerini karşılaştırılmış ve bunlardan SYİ yönteminin diğer yöntemlere kıyasla meteorolojik kuraklığı tanılamakta daha tutarlı olduğu gösterilmiștir [7]. Polonya'da 2005 yılından itibaren, kuraklık izleme sistemlerinde $1,2,3,6,12,24,36$ ve 48 aylık dönemlerdeki meteorolojik kuraklıklarının belirlenmesinde SYİ yönteminin etkin bir biçimde kullanıldığı belirlenmiştir [10]. Endenozya'da meydana gelen El Nino dönemlerindeki (Haziran-Kasım) 1, 3, 6, 9 ve 12 aylık kuraklıkları SYİ ile tanımlanmış ve El Nino dönemlerinde meteorolojik kuraklığın her ay arttığını ve Ekim ayında en șiddeti kuraklığın yaşandığı tespit edilmiştir [11]. Benzer şekilde, 1981-2010 yılları arasında Bangladeş'te meydana gelen kuraklıkları, 30 meteoroloji gözlem istasyonunun yağış verilerinden hesaplanan SYI'ler ile tanımlamış ve kuraklık haritaları hazırlanarak Bangladeş'te kuraklığın ortalama 2.5 yıl sürdüğü ve ülkenin kuzey, güney-batı ve doğu bölgelerinde kuraklığın diğer bölgelere kiyasla daha güçlü görüldüğü belirlenmiştir [12]. Türkiye'de 60 büyük klima istasyonun 1930-1990 yılları arasındaki aylık yağıș verilerini kullanarak meteorolojik kuraklıkların genliğini, süre ve şiddetini SYI yöntemi ile belirleyip ülke geneli için haritalandırılmıștır [13].

Ülkemizde il ve havza ölçeğinde meydana gelen kuraklıkların belirlenmesinde SYİ indis yöntemi sıklıkla kullanılmaktadır. [14-17]. Çanakkale ilinin kuraklık analizleri 1929-2007 yılları arasındaki aylık yağış verileri kullanılarak 3 aylık (mevsimlik) ve 12 aylık (yıllık) SYİ yöntemi ile yapılmıștır. Çalıșma sonucunda, Çanakkale ilinde yıllık kuraklıkların arttığı, mevsimlik kuraklık değişimlerinde kış mevsimi kuraklığında önemli bir artış eğilimi olduğu buna karşın ilkbahar mevsimi kuraklığında azalma eğiliminde olduğu belirlenmiștir. Aynı çalışmada, yaz ve sonbahar kuraklıklarında az da olsa azalma eğiliminin varlığı gösterilmiștir [14]. Ayrıca Kırıkkale ilinde meydana gelen meteorolojik kuraklıklar, 1950-2007 yılları arası dönem için 1, 3, 6, 9, 12 ve 24 aylık periyotlar SYİ yöntemi ile incelenmiştir. Kırıkkale ilinde yaşanan meteorolojik kuraklıkların kısa dönemlerden uzun dönemlere doğru gidildikçe kuraklık sıklığının azaldığını, kuraklık genliklerinde ve sürelerinde artış olmasıyla beraber, ortalama kuraklık şiddetinde azalma yönünde değişimlerin oluştuğunu tespit edilmiştir [15]. Havza ölçeği bazında yapılan çalışmalarda, Kızılırmak Havzası'nda 1973-2013 yılları arasında meydana gelen kuraklıklar Nevşehir, Kırşehir, Kayseri, Yozgat, Kırıkkale, Çankırı ve Kastamonu'nda gözlemlenen aylık yağıș değerlerini kullanarak SYİ yöntemi ile 1, 3, $6,9,12$ ve 60 aylık periyotlar için belirlemiştir. Kızılırmak Havzası'nda 1, 3, 6, ve 9 aylık periyotlarda az sayıda çok șiddetli kuraklığın meydana gelirken 12 ve 60 aylık periyotlarda çok şiddetli kuraklı̆̆ın hiç yaşanmadığını belirlenmiștir. Ayrıca incelenen dönem sürelerinin artmasına paralel, yaşanan kuraklık sürelerinin 3 ile 7 kat arttığını tespit edilmiştir. [8]. Seyhan ve Ceyhan Havzası'nın meteorolojik 
DEU FMD 21(62), 509-523, 2019

kuraklıklarını 1970-2005 su yılları arasındaki 3, 6 ve 12 aylık dönemler için incelenmiș ve çalıșma sonucunda zamansal boyutunda sadece 1988 yılında așırı kuraklığın yașandığı, mekan boyutunda ise 1972 yllinda incelenen istasyonların yaklaşık \%31'inde aşırı kuraklığın meydana geldiği belirlenmiştir [16].

Sunulan çalışma kapsamında da iç Ege bölgesinde yer alan Yukarı Gediz Havzası'nda 1960-2017 yılları arasında meydana gelen kuraklıklar incelenmiştir. Bölgedeki Demirci, İçikler, Kula, Selendi, Gediz ve Uşak meteoroloji istasyonlarında gözlenen aylık yağış verilerine kullanılarak aylık, mevsimlik ve yıllık periyotlarda SYI değerleri hesaplanmıș ve bu dönemde görülen kuraklıkların șiddet ve süreleri her bir dönem için tanımlanmıştır.

\section{Materyal ve Metot 2.1. Uygulama alanı}

Batı Anadolu'da yer alan Gediz Havzası yaklaşık $17500 \mathrm{~km}^{2}$ 'lik drenaj alanına sahip olup Türkiye genel yüz ölçümünün \%2,2'sini kapsamaktadır. Havzaya ismini veren Gediz Nehri $275 \mathrm{~km}$ uzunluğunda olup Ege denizinde boşalmaktadır. Yukarı Gediz Havzası, havzadaki en önemli su yapısı olan Demirköprü barajının memba kesimini tanımlamaktadır (Şekil 1). Taşkın koruma, enerji ve büyük ölçüde sulama suyu temini amaçlı inșaa edilen Demirköprü Barajı $5520 \mathrm{~km}^{2}$ drenaj alanına sahip olup havzadaki 99200 hektarlık Adala, Ahmetli ve Emiralem sulamalarının ana su kaynağıdır. Baraj Gediz Nehri'nin Demirci, Deliiniș, Selendi ve Acısu kollarından beslenmektedir.

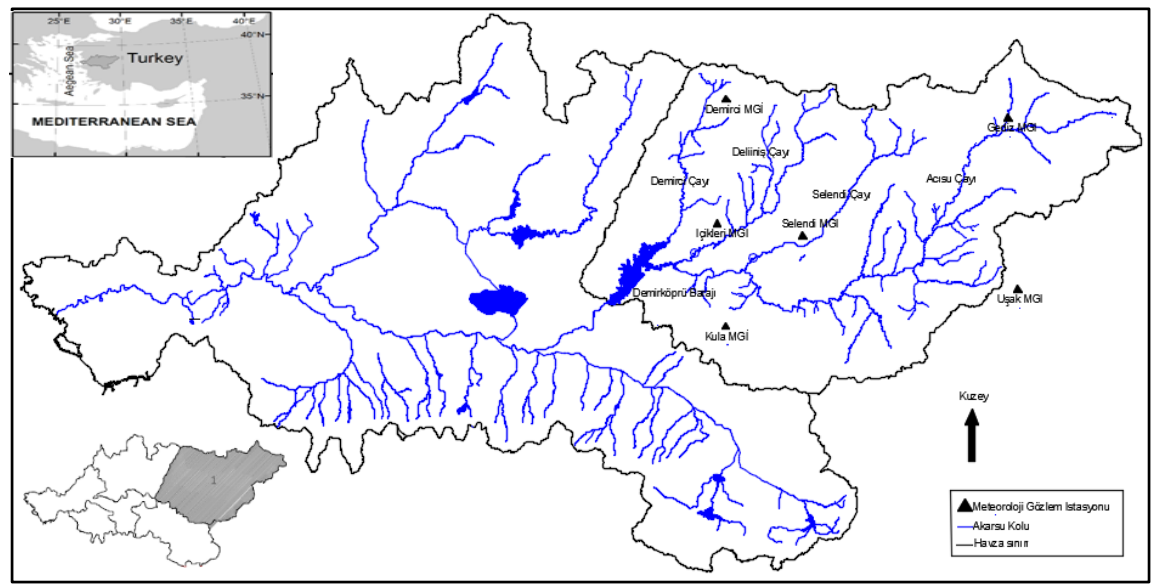

Şekil 1. Yukarı Gediz Havzası ve meteoroloji gözlem istasyonları

Çalışma kapsamında, Demirköprü Baraj haznesini besleyen Yukarı Gediz bölgesi ve çevresindeki Demirci, İcikler, Kula, Selendi, Gediz ve Uşak yağış gözlem istasyonlarının 1960-2017 yılları arasında gözlenmiș aylık toplam yağıș değerleri kullanılarak, kuraklık analizleri gerçekleștirilmiștir (Şekil 1). Çalıșmada kullanılan istasyonların koordinat bilgileri ve temel istatistikleri Tablo 1'de özetlenmektedir. Kot olarak 475 m ile 919 m arasında dağılım gösteren meteoroloji istasyonlarının maksimum aylık yağış değerleri 211,1 mm ile 267,8 mm arasında değișim gösterirken, ortalama yağıș değerleri 41,8 ile 53,2 $\mathrm{mm}$ arasında değișmektedir (Tablo 1). 
DEU FMD 21(62), 509-523, 2019

Tablo 1. Yukarı Gediz Havzası meteorolojik kuraklıkların belirlenmesinde kullanılan yağış gözlem istasyonlarının coğrafi bilgileri ve temel istatistikleri

\begin{tabular}{|c|c|c|c|c|c|c|}
\hline İstasyon adı & Enlem & Boylam & $\begin{array}{l}\text { Kot } \\
(\mathrm{m})\end{array}$ & $\begin{array}{c}\text { Maksimum } \\
\text { yağış } \\
\text { (mm/ay) }\end{array}$ & $\begin{array}{c}\text { Ortalama } \\
\text { yağış } \\
\text { (mm/ay) }\end{array}$ & $\begin{array}{l}\text { Standart } \\
\text { sapma } \\
\text { (mm/ay) }\end{array}$ \\
\hline Demirci & $39^{\circ} 03^{\prime} 49^{\prime \prime}$ & $28^{0} 64^{\prime} 82^{\prime \prime}$ & 855 & 264,8 & 53,2 & 51,3 \\
\hline İcikler & $38^{0} 79^{\prime} 39^{\prime \prime}$ & $28^{0} 59^{\prime} 60^{\prime \prime}$ & 710 & 242,6 & 47,1 & 45,4 \\
\hline Kula & $38^{0} 52^{\prime} 72^{\prime \prime}$ & $28^{0} 63^{\prime} 68^{\prime \prime}$ & 720 & 267,8 & 46,3 & 44,9 \\
\hline Selendi & $38^{0} 75^{\prime} 11^{\prime \prime}$ & $28^{0} 86^{\prime} 39^{\prime \prime}$ & 475 & 226,9 & 41,8 & 36,8 \\
\hline Gediz & $38099^{\prime} 47^{\prime \prime}$ & $29^{\circ} 40^{\prime} 03^{\prime \prime}$ & 736 & 260,5 & 48,6 & 45,3 \\
\hline Uşak & $38^{0} 67^{\prime} 12^{\prime \prime}$ & $29^{\circ} 40^{\prime} 40^{\prime \prime}$ & 919 & 211,0 & 44,8 & 37,8 \\
\hline
\end{tabular}

\subsection{Standartlaştırılmış yağış indeksi (SYì)}

MckKee vd (1993) tarafından geliștirilen SYİ, meteorolojik kuraklığın niceliksel hale dönüştürülmesinde uluslararası kabul görmüş boyutsuz bir göstergedir [4, 17]. SYİ, gamma dağılımı ile temsil edilen pozitif çarpık yağış dizilerinin, eşdeğer normal dağılımlı hale dönüştürülmesinden sonra standardize edilmesiyle elde edilmektedir [17]. Çeşitli periyodlarda gözlenmiş yağışlara ait SYİlerin yeterli doğrulukta belirlenebilmesi için en az 30 yıllık veriyle hesaplanmalıdır [16, 17]. SYİler hesaplanmadan önce, yağıș verilerine Gamma olasılık yoğunluk fonksiyonu (Denklem 1) uydurularak dağılım fonksiyonunun parametreleri belirlenmelidir.

$$
f(x)=\frac{1}{\beta^{\alpha} \Gamma(\alpha)} x^{\alpha-1} e^{-x / \beta}
$$

Denklem 1'de x yağış miktarlarını (mm/ay), $\alpha$ dağllımın şekil parametresini, $\beta$ ölçek parametresini, $\Gamma(\alpha)$ ise Gamma fonksiyonunu ifade etmektedir. Gama dağılımının $\alpha$ ve $\beta$ parametreleri, örnek veri sayısına bağlı olarak Denklem 2 ila 4 arasında verilen bağıntılarla hesaplanabilmektedir.

$$
A=\ln (\bar{x})-\frac{\sum \ln (x)}{n}
$$

Denklem 2 'te $\bar{x}$ yağış verilerinin ortalamasını, $\mathrm{n}$ veri sayısını göstermektedir.

$$
\alpha=\frac{1}{4 A}\left(1+\sqrt{1+\frac{4 A}{3}}\right)
$$

$$
\beta=\bar{x} / \alpha
$$

$\alpha$ ve $\beta$ parametrelerinin bulunmasiyla herhangi bir aydaki yağış değerinin kümülatif olasılık değeri Denklem 5 ile hesaplanabilmektedir.

$$
F(x)=\frac{1}{\beta^{\alpha} \Gamma(\alpha)} \int_{0}^{x} x^{\alpha-1} e^{-x / \beta} d x \quad x>0
$$

Gamma fonksiyonu x'in 0 değerleri için tanımsız olduğundan, yağış olmayan periyodlara ait kümülatif olasılık değerleri Denklem 6 ile hesaplanmaktadır.

$$
H(x)=q+(1-q) F(x)
$$

Burada $q$, verilerdeki yağıșsız veri sayısının (m) toplam veri sayısına (n) bölümü ile hesaplanır $(q=m / n) . H(x)$ değerleri Denklem 7 ve 8 ile ortalaması 0 ve varyansı 1 olan SYİ indis değerlerini ifade eden standart normal Z değișkenine dönüștürülmektedir.

$$
\left.t=\sqrt{\left\{\ln \left[\frac{1}{H(x)^{2}}\right]\right\}} \quad 0<H(x)\right) \leq 0.5
$$




$$
\begin{aligned}
& t=\sqrt{\left\{\ln \left[\frac{1}{1-H(x)^{2}}\right]\right\}} \quad 0.5<H(x) \leq 1.0 \\
& S P I=-\left(t-\frac{c_{0}+c_{1} t+c_{2} t^{2}}{1+d_{1} t+d_{2} t^{2}+d_{3} t^{3}}\right) \\
& 0<H(x) \leq 0.5 \\
& S P I=+\left(t-\frac{c_{0}+c_{1} t+c_{2} t^{2}}{1+d_{1} t+d_{2} t^{2}+d_{3} t^{3}}\right) \\
& 0.5<H(x) \leq 1.0
\end{aligned}
$$

Denklem 7 ve 8'de yer alan $H(x)$, yağıș verilerinin kümülatif olasılık değerlerini; $c_{0}, c_{1}$, $c_{2}, d_{1}, d_{2}, d_{3}$ katsayıları ise eșdeğer normal dağılımlı standardize değişken dönüşümünü gerçekleștiren katsayıları göstermektedir. $\mathrm{Bu}$ katsayılar sirasiyla, 2.515517, 0.802853, $0.010328,1.432788,0.189269$ ve 0.001308 sabit değerlerini almaktadır $[16,18]$.

Gözlenmiș yağıș verileriyle hesaplanan SYİ değerlerinin kuraklık sınıflandırması Tablo 2'de verilmektedir [16].

Tablo 2. SYİ indislerinin sınıflandırması [16]

\begin{tabular}{ll}
\hline SYİ indisleri & Kuraklık Sinıfları \\
\hline SYI $\leq-2$ & Çok şiddetli kurak \\
$-2<$ SYI $\leq-1.5$ & Şiddetli kurak \\
$-1.5<$ SYİ $\leq 1$ & Orta şiddetli kurak \\
$-1<$ SYI $\leq 0$ & Hafif şiddetli kurak \\
$0<$ SYİ $\leq 1$ & Hafif şiddetli sulak \\
$1<$ SYİ $\leq 1.5$ & Orta şiddetli sulak \\
$1.5<$ SYİ $\leq 2$ & Şiddetli sulak \\
SYI $>2$ & Çok şiddetli sulak \\
\hline
\end{tabular}

\section{Bulgular}

\subsection{Yukarı Gediz Havzası yağışlarının} meteorolojik kuraklık analizi

Yukarı Gediz Havzası'nda bulunan Demirci, İcikler, Kula, Selendi, Gediz ve Uşak yağış gözlem istasyonlarında 1960-2017 yılları arasında gözlenen aylık yağıșların SYİ değerleri aylık, mevsimlik ve yıllık periyotlar için ayrı ayrı hesaplanmış ve elde edilen bulgular aşağıda başlıklar halinde sunulmuştur.

\subsubsection{Yukarı Gediz Havzası aylık yağışların meteorolojik kuraklık analizi}

Yukarı Gediz Havzası'nda 1960-2017 yılları arasında gözlemlenen aylık yağışların Ocak ve Haziran ayları arasındaki aylık SYİ değerlerinin gidiş grafikleri Şekil 2'de, bu aylardaki kuraklık sınıflarının görülme sıklıklar ise Şekil 3'te verilmektedir.

İncelenen Ocak ve Haziran arasındaki aylarının hepsinde 1988-1992, 1995-1999 yılları arasında ve 2008 yllında Yukarı Gediz Havzasında kurak dönemlerin oluştuğu Şekil 2'den görülmektedir. Ocak ayları 1988-1995 yılları arasındaki 8 yıl boyunca sürekli kurak geçmiş ve 1992 yılında çok şiddetli kuraklıkla karşılaşılmıștır. Şubat aylarında bu dönem 1987-1992 yılları arasında 6 yıl süresince oluşmuş ve çok şiddetli kuraklıklar 1989 ve 2008 yıllarında yașanmıștır. Ayrıca Şubat ayları için havza düșen yağıșlarda 2014 yılından itibaren de kurak dönemin süregeldiği Şekil 2'den görülmektedir. Havzada Mart aylarında yaşanan çok şiddetli kuraklıkların 1983, 1985, 2003 ve 2004 yıllarında olușmuş ve en uzun kurak dönemin 1989-1992 yılları arasında 4 yıl boyunca devam ettiği görülmektedir. Nisan aylarında çok şiddetli kuraklık 1998 yılında görülürken bu ayda en uzun kurak dönem 2004-2011 yılları arasında 8 yıl sürmüștür. Mayıs yağıșlarında ise 1984-1990 yılları arasında en uzun kurak dönem meydana gelmesine karşın, çok şiddetli kuraklıklar 1962, 1981, 1999 ve 2008 ylllarında gerçekleşmiştir. Haziran yağışlarında çok şiddetli kuraklık sadece Uşak yağışlarında olmasıyla birlikte en uzun kurak dönem 1995-2009 yılları arasında 15 yıl boyunca sürmüştür (Şekil 2). 

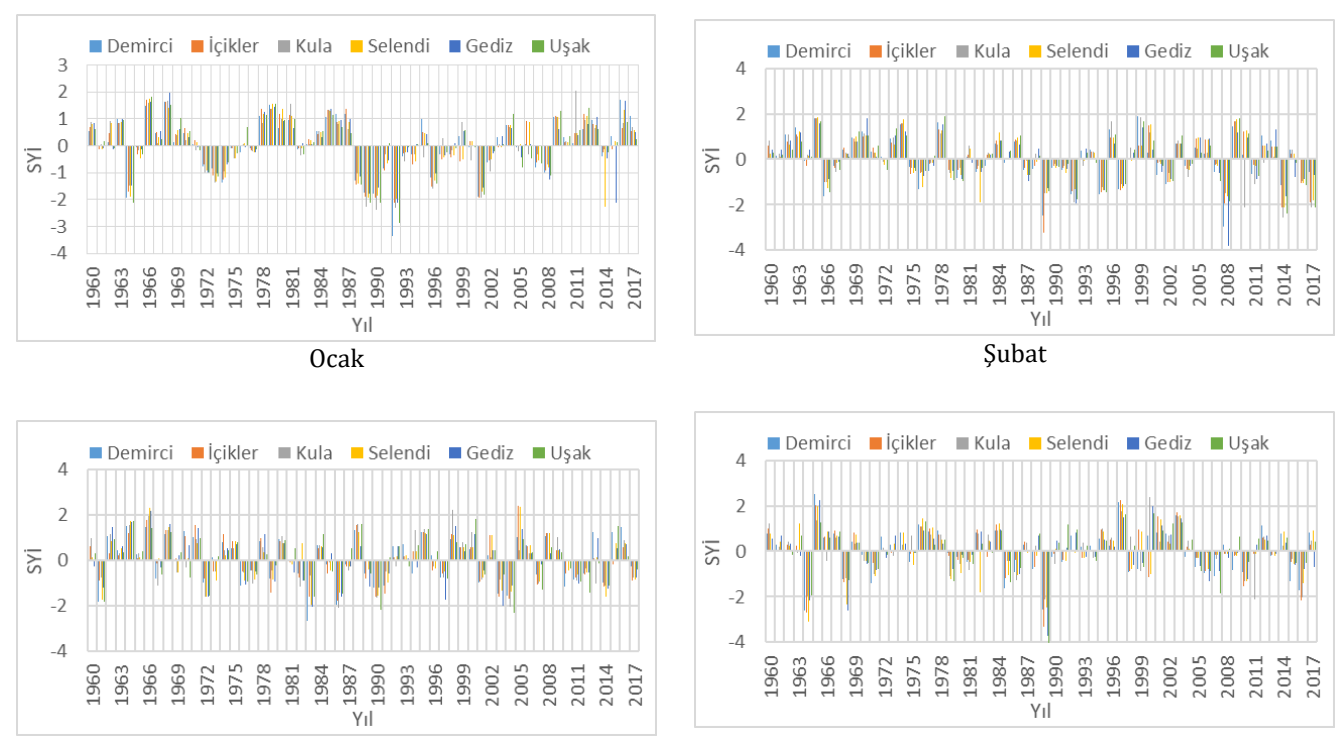
Mart

Nisan
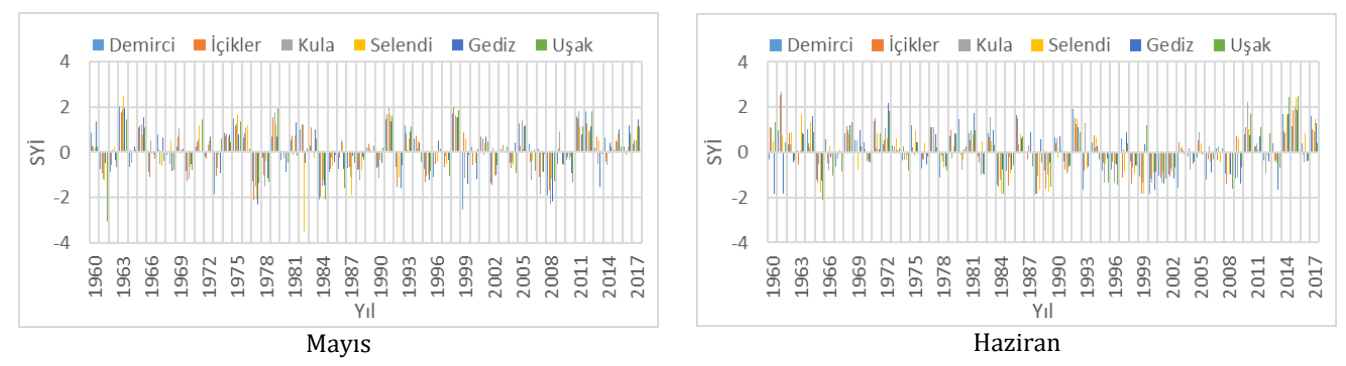

Şekil 2. Yukarı Gediz Havzası 1960-2017 yılları arası yağışlarının Ocak-Haziran dönemi SYì kuraklık indislerinin gidişi.

Șekil 3'te verilen Ocak-Haziran döneminde meydana gelen kuraklık sınıflarının görülme sıklıkları incelendiğinde, havzada genellikle hafif şiddeti kurak ve hafif şiddetli sulak sinıflar görülmektedir. Ocak, Şubat, Nisan ve Mayıs aylarına ait yağışlarda istasyonlarının hepsinde çok şiddetli kurakların en az bir kez gözlenmesi dikkat çekicidir. Mart aylarında İcikler ve Selendi yağışlarında, Haziran aylarında ise Uşak yağıșlarında çok șiddetli kuraklık sınıfı hiç görülmemiştir Şiddetli kuraklık sınıfı Nisan ayları için Gediz yağışlarında, Haziran ayları için Kula yağışlarında görülmeyip kalan diğer aylarda en az iki kez meydana gelmiştir. Orta şiddetli kuraklık sınıfı yalnızca Haziran aylarında Selendi yağışlarına görülmemiş, diğer tüm aylara ait yağıșlarda sıklıkla gözlemlenmiştir. 

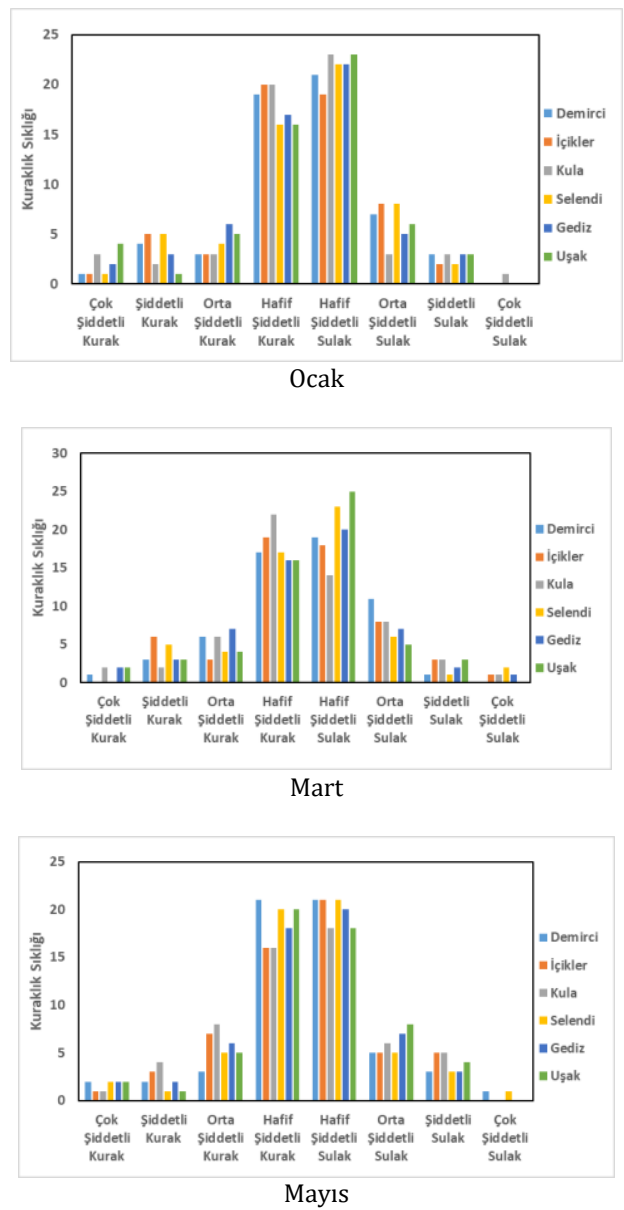
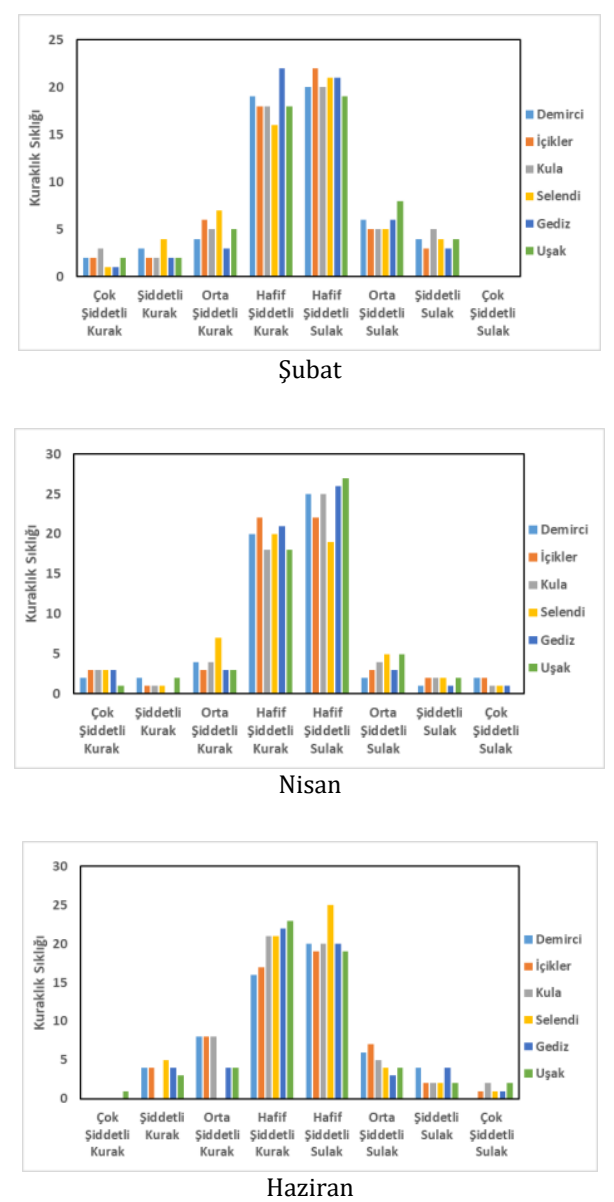

Şekil 3. Yukarı Gediz Havzası 1960-2017 yılları arası yağıșlarda gözlenen kuraklıkların OcakHaziran dönemindeki sıklıkları.

Ocak-Haziran dönemine benzer şekilde, Yukarı Gediz Havzası'nda 1960-2017 yılları arasında gözlemlenen aylık yağıșların Temmuz ve Aralık dönemleri için hesaplanan aylık SYİ değerlerinin gidiş grafikleri ve bu dönemdeki görülme sıklıkları sırasıyla Şekil 4 ve Şekil 5'de verilmektedir.

Şekil 4'te Temmuz yağışlarında kuraklık döneminin 2007-2012 yılları arasında 6 yıl süresince devam ettiği görülmektedir. Ağustos aylarında genelde kuraklıklar kısa süreli oluşmasında karşın en uzun kuraklık dönemi 7 yıl boyunca 1960-1966 yılları arasında yaşanmıştır. Eylül aylarında en uzun kurak dönem 1991-1994 yılları arasında, Ekim yağışlarında ise 1964-1969 yılları arasında görülmüștür. Ayrıca Șekil 4'ten Temmuz ve Ekim ayları arasındaki yağışlarda 1960-2017 periyodunda çok şiddetli kuraklıkların meydana gelmediği görülmektedir. Kasım ayları için en uzun kurak dönem 2010-2013 yılları arasında görülürken 2010 yılından önceki yıllarda kurak dönemlerin kısa sürelerle meydana geldiği görülmektedir. $\mathrm{Bu}$ ayda çok şiddetli kuraklık 2011 yılında görülmüștür. Aralık ayları yağışlarının kuraklık değişimlerinde 1960-1970 yıllar arası sulak olarak geçmesine karşın son yıllara doğru kurak dönemlerin daha yoğun ve uzun süreli meydana geldiği ayrıca sulaklık şiddetlerinin de azaldığg görülmektedir. $\mathrm{Bu}$ aydaki en uzun kuraklık süresi 5 yll olarak 19911995 yılları arasında görülmüștür. Çok şiddetli kurak dönemler ise 2013 ve 2015 yllarında meydana gelmiştir (Şekil4). 

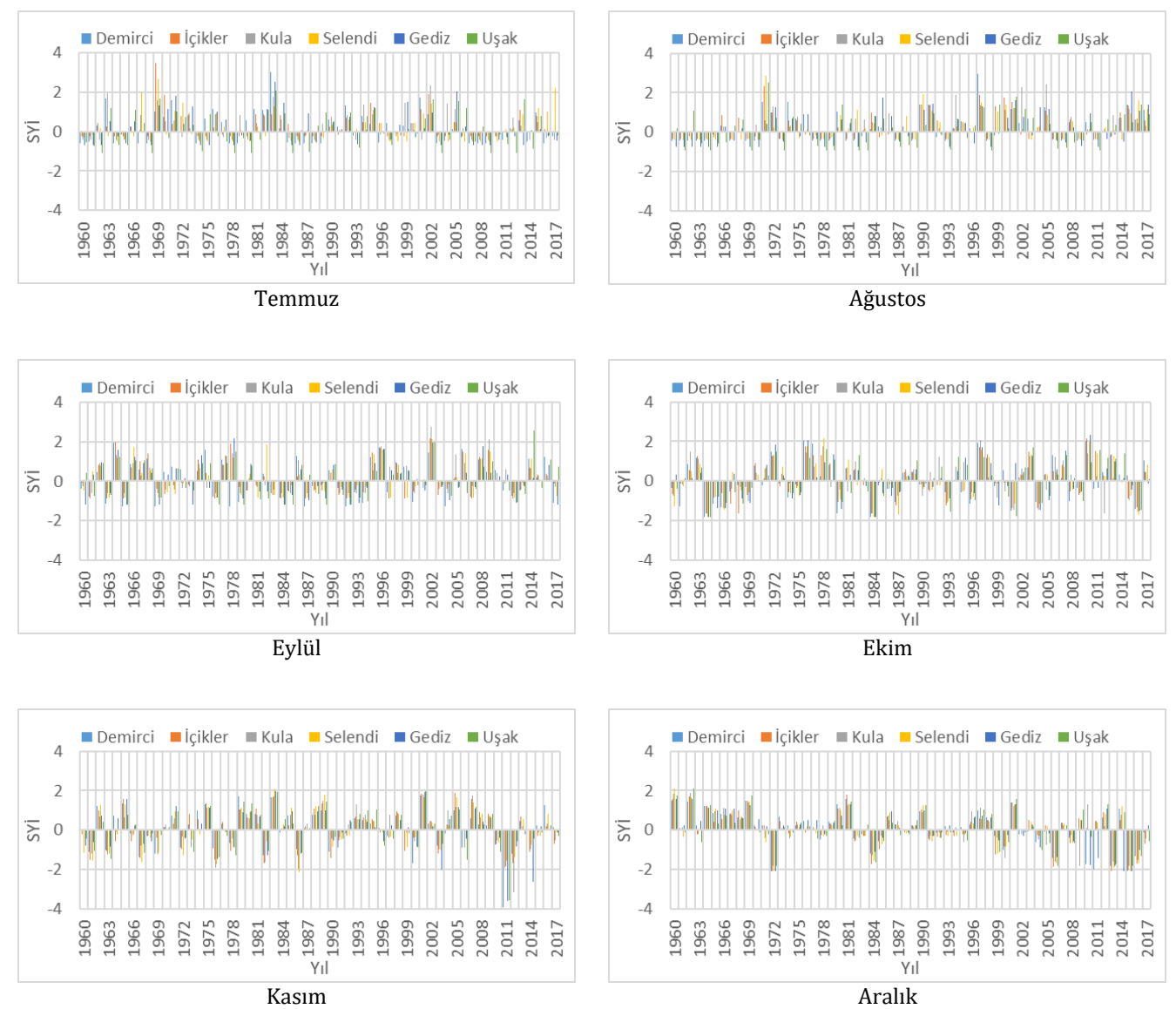

Şekil 4. Yukarı Gediz Havzası 1960-2017 yılları arası yağıșlarının Temmuz-Aralık dönemi SYİ kuraklık indislerinin gidişi

Șekil 5'te verilen Yukarı Gediz Havzası TemmuzAralık dönemi yağışlarının kuraklık sınıfları incelendiğinde, havzadaki yağıșların genel olarak hafif şiddetli kurak ve hafif şiddetli sulak sınıflarda meydana geldiği görülmektedir. Temmuz-Ekim arası aylarda en sık görülen kuraklık sınıfı hafif şiddetli kurak sınıfıdır. Kasım ve Aralık aylarında ise hafif şiddetli sulak sınıfların daha sık oluştuğu görülmektedir. Temmuz-Ekim arasındaki aylarda çok șiddetli kuraklık sınıfının oluşmadığı görülmektedir. Bu sınıf benzer şekilde Kasım ayında İcikler yağışlarında, Aralık ayında da Kula ve Uşak yağıșlarında hiç görülmemiștir. Șiddetli kuraklık sınıfı Temmuz-Eylül arasında yağışlarda ve Kasım aylarındaki Gediz yağışlarında meydana gelmezken, orta şiddetli kuraklık sınıfı Ağustos yağışlarında hiç görülmemiştir. Orta şiddetli kuraklıklar Ekim, Kasım ve Aralık ayları yağışlarının hepsinde en az 5 kez görülmesine karşın, Temmuz aylarında sadece Uşak yağışlarında ve Eylül aylarında Demirci, Gediz ve Uşak yağışlarında gözlenmiştir. 

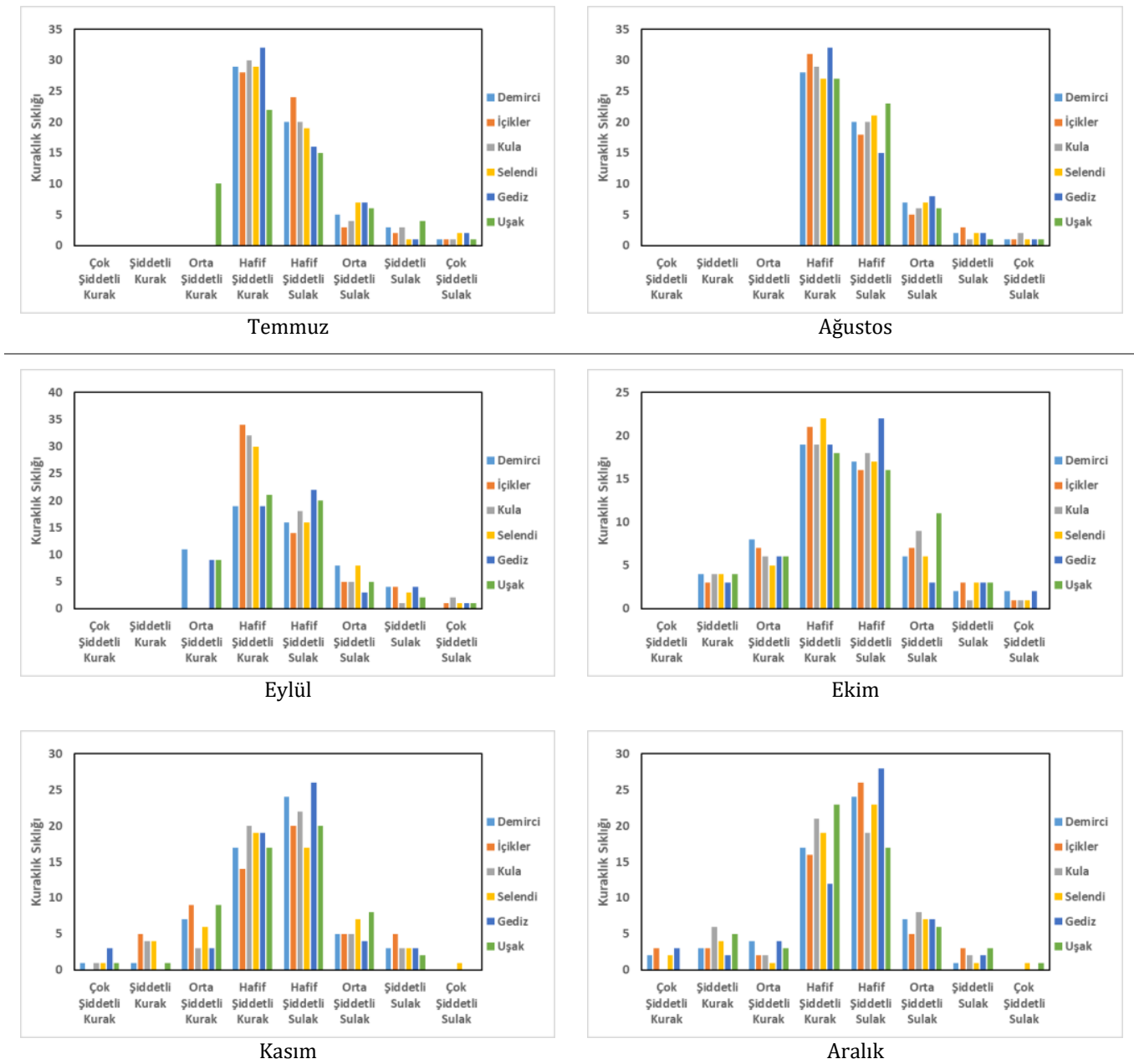

Şekil 5. Yukarı Gediz Havzası 1960-2017 yılları arası yağıșlarda gözlenen kuraklıkların TemmuzAralık dönemindeki sıklıkları.

\subsubsection{Yukarı Gediz Havzası mevsimlik yağışlarının meteorolojik kuraklık analizi}

Yukarı Gediz Havzası mevsimsel kuraklıklarının analizinde kış, ilkbahar, yaz ve sonbahar mevsimlerinde düșen toplam yağışlar kullanılarak SYİ değerleri hesaplanmıștır. Havzada mevsimsel yağışların SYİ değerleri Şekil 6'da, kuraklık sınıflarının görülme sıklıkları ise Şekil 7'de verilmektedir.

Şekil 6'da yer alan Kıș mevsimi SYİ değerleri, en uzun kuraklık periyodunun 1988-1995 yllları arasında oluştuğunu göstermektedir. Çok şiddetli kuraklıklar 1972, 1992 ve 2008 yıllarında görülmüștür. Havzada kıș mevsimi yağışlarının 2013 yılından itibaren kuraklık sürecinde olduğu görülmektedir. Ayrıca 1970 yılından sonraki kış mevsimleri yağışlarında kuraklık olaylarının daha sık meydana geldiği izlenmektedir. İlkbahar mevsimi yağışlarının SYİ indislerinin değișimi incelendiğinde, 1985-1991 yılları arasında (1986 yılı hariç) çok şiddetli ve şiddetli kurak dönemlerin yaşandığı görülmektedir. İlkbahar mevsim yağıșlarında özellikle 2000 yılından sonraki yıllarda sulaklık şiddetlerinde azalmanın olduğu ve buna karşıllk kuraklık şiddetlerinin de arttığı görülmektedir. Yaz mevsimi yağışlarına ait SYI değerleri incelendiğinde nispeten düșün yağışların gözlendiği bu mevsimde, 1960-2017 yılları arasında sulak dönemlerin daha hakim olduğu 
görülmektedir. Yaz mevsimlerinde en uzun kuraklığın, 1987-1990 ve 2006-2009 yılları arasında sırasıyla 4 yıl süresince şiddetli ve çok șiddetli kurak sinıflarında oluștuğu görülmektedir. Sonbahar mevsimleri yağışlarının SYİ değişimlerinden, havzada kurak dönemlerin daha seyrek meydana geldiği Kış

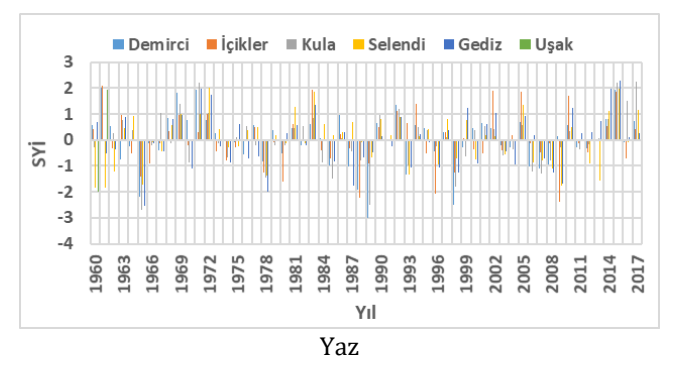

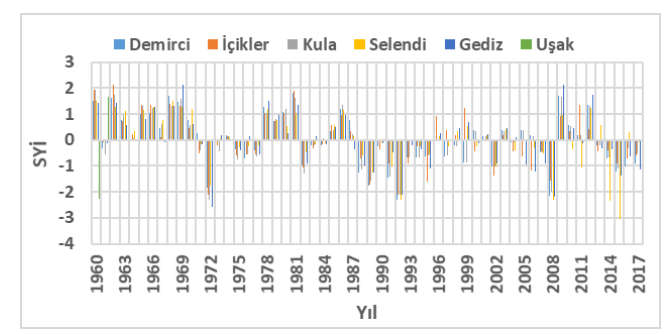

görülmektedir. Bu mevsimde çok şiddetli kurak dönemler 1960, 1961 ve 2012 yıllarında meydana gelmiş ve en uzun kuraklık periyodu 1966-1969 yılları arasında 4 yıl sürmüștür (Șekil 6).
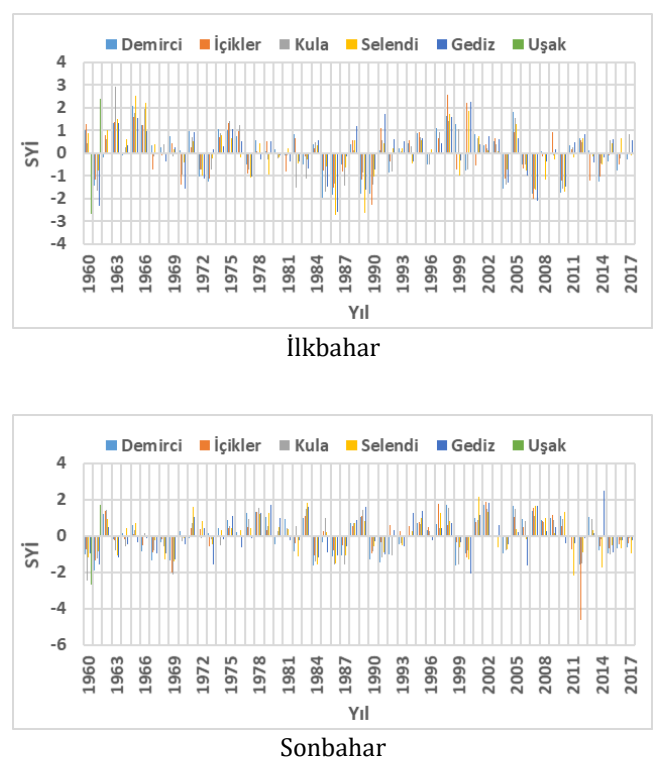

Şekil 6. Yukarı Gediz Havzası 1960-2017 yılları arası mevsimsel yağıșların SYİ değerleri.

Șekil 7'de 1960-2017 periyodu için mevsimsel yağışlarda gözlemlenen kuraklık sıklıkları verilmektedir. Mevsimsel kuraklıkların görülme sıkları incelendiğinde, kuraklığın genel olarak aylık yağışlardakine benzer şekilde hafif şiddetli kurak ve hafif șiddetli sulak sınıfında oluștuğu görülmektedir. Kış mevsiminde çok şiddetli kuraklık sınıfının havzadaki tüm istasyonlarda en az 2 kez meydana geldiği görülmektedir. İlkbahar mevsiminde İcikler ve Selendi yağıșlarında, Yaz mevsiminde Demirci ve Gediz yağışlarında, Sonbahar mevsiminde de İcikler yağıșlarında çok șiddetli kuraklık sınıfı hiç oluşmamıştır. Şiddetli kuraklık sınıfı, Kış mevsiminde Ușak yağıșlarında ve Sonbahar mevsiminde Kula yağışlarında oluşmazken orta ve hafif şiddetli kuraklık sınıfları havzadaki tüm mevsimsel yağıșlarda sırasıyla en az 5 ve $20 \mathrm{kez}$ meydana gelmiștir. Havzada en slk görülen kuraklık sınıfı olan hafif şiddetli kuraklık incelenen zaman periyodu içerisinde en çok Kış, en az İlkbahar mevsimlerinde görülmektedir (Şekil 7). 

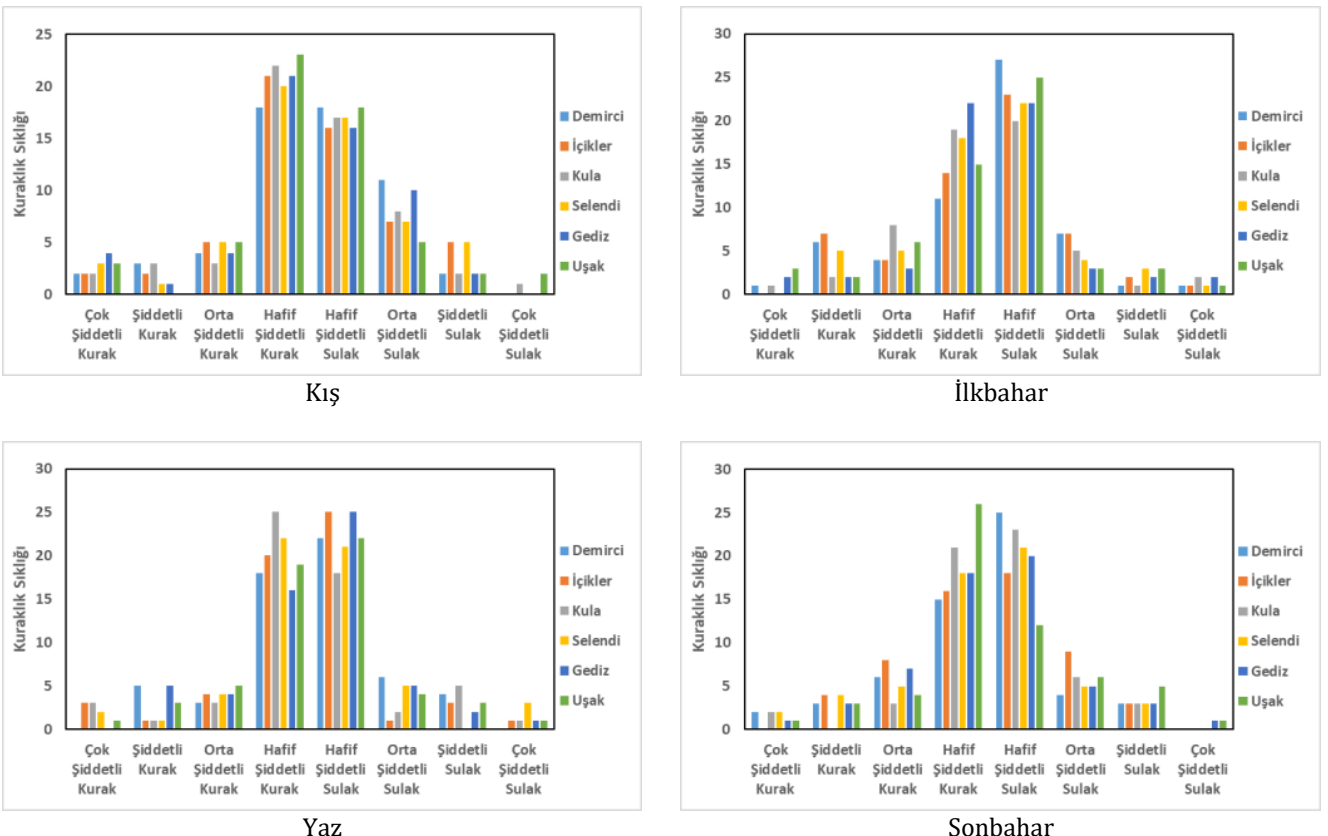

Şekil 7. Yukarı Gediz Havzası 1960-2017 yılları arası mevsimsel yağışların kuraklık sıklıkları.

\subsubsection{Yukarı Gediz Havzası yağışlarının yıllık meteorolojik kuraklık analizi}

Yukarı Gediz Havzası yıllık yağışlarının kuraklık analizinde, 1960-2017 yılları arasında gözlemlenen yıllık toplam yağıșlar kullanılarak SYİ değerleri hesaplanmış ve yıllara göre değişimi Şekil 8'de, sıklıkları ise Şekil 9'da verilmiştir.

Şekil 8'den, havzada 1962-1971 yılları arasındaki dönemin sulak olarak yaşandığı görülmektedir. Havzada meydana gelen en uzun yıllık kuraklık periyodunun, 1984-1996 yılları arasındaki 12 yıllık dönem olduğu görülmektedir. Kuraklığın yıllar bazında değerlendirilmesinde 1960-2017 arası gözlemlenen yağışlara istinaden 1980 sonrası yıllarda kurak dönem periyotlarının sulak döneme göre daha sık ve uzun sürdüğü görülmektedir. 1961, 1987, 2006, 2008, 2011 ve 2014 yıllarında meydana gelen kuraklıkların çok șiddetli kuraklık sınıfında olduğu, 2010 sonrası havza yağıșlarının bölge içinde değișkenlik gösterdiği dikkati çekmektedir. Örneğin 2014 yılı Demirci ve Uşak istasyonları için sulak bir yıl iken, İcikler, Kula, Selendi ve Gediz istasyonlarında kuraklık yaşandığı görülmektedir (Şekil 8). 


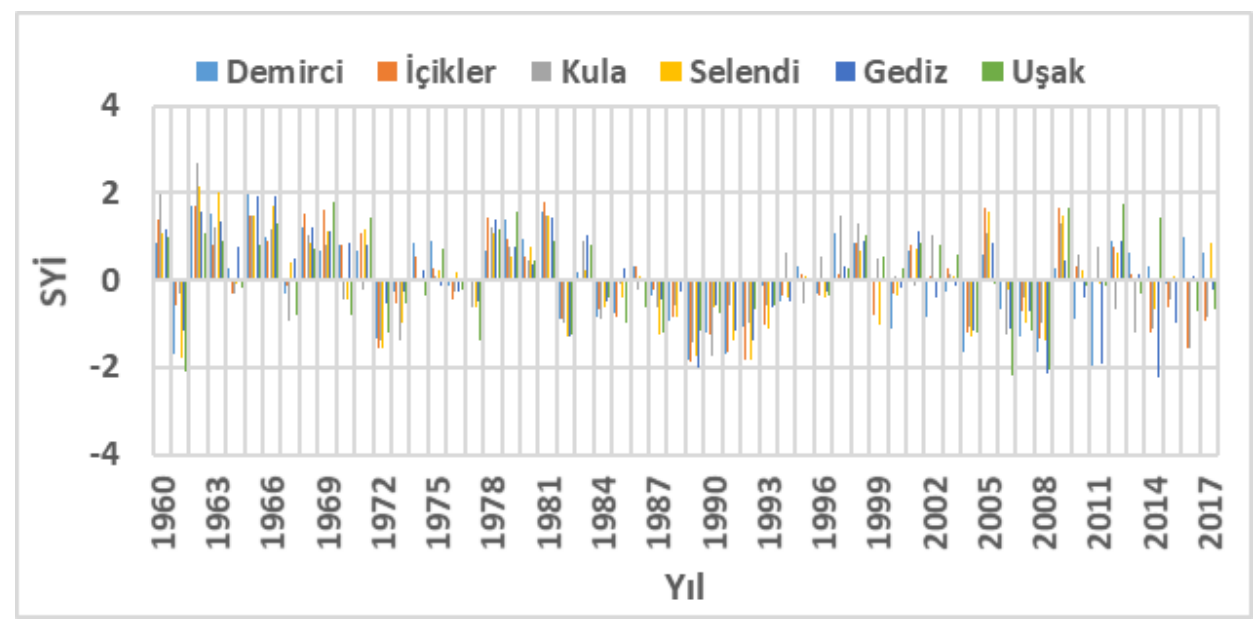

Şekil 8. Yukarı Gediz Havzası 1960-2017 yılları arası yağışların yıllık periyottaki SYİ kuraklık indisleri

Şekil 9'da verilen kuraklık sınıflarının görülme sıklıkları incelendiğinde havzada hafif şiddetli kuraklık ve hafif şiddetli sulaklık sınıfının en sık gözlenen sınıflar olduğu görülmektedir. Çok şiddetli kuraklık sadece Gediz ve Ușak yağışlarında en az $3 \mathrm{kez}$ gözlenirken, şiddetli kuraklık sınıfı Ușak istasyonu haricinde tüm istasyonlarda 1-4 kez görülmüş ve en slk ise
Demirci yağışlarında (6 kez) meydana gelmiştir. Orta şiddetli kuraklık sınıfları havzadaki tüm istasyonlar da en az 5 kez gözlenirken, hafif şiddetli kuraklıklar aynı istasyonlarda en az 15 kez tekrar etmiştir.

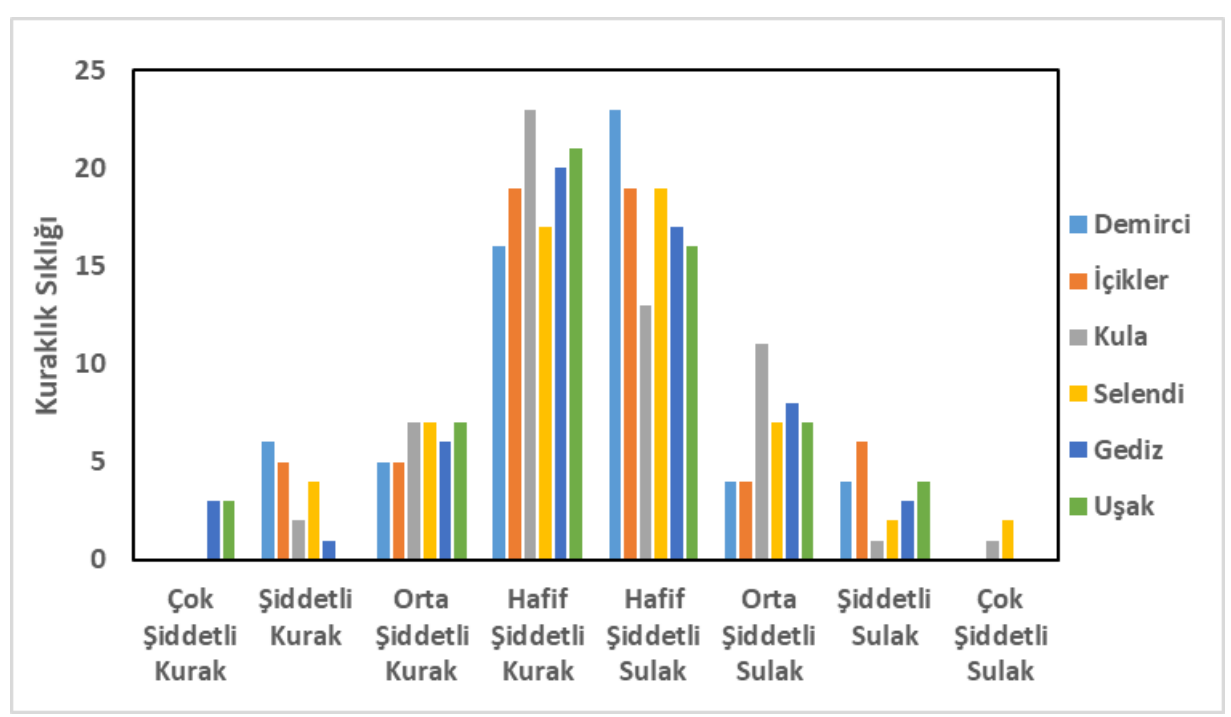

Şekil 9. Yukarı Gediz Havzası 1960-2017 yılları arası yağışların yıllık periyottaki kuraklıkların görülme sıklığı 


\section{Tartışma ve Sonuç}

Yukarı Gediz Havzasında yer alan Demirci, İcikler, Kula, Selendi, Gediz ve Uşak meteoroloji istasyonlarında 1960-2017 yılları arasındaki 47 yıllık dönemde ölçülen aylık yağışlarından hareketle, aylık, mevsimlik ve yıllık yağışların kuraklık analizleri SYİ yöntemiyle incelenmiștir. Havzaya düşen yağışların aylık ve mevsimsel kuraklıkları ile mevsimsel ve yıllık kurakları birbirleriyle karşılaştırılarak irdelenmiștir.

Kıș mevsimi yağıșlarında 1962-1970 arasındaki dönemde kuraklık gözlenmezken aylık bazda Ocak ve Şubat aylarında kuraklıkların meydana gelmesi bu dönemdeki Aralık yağıșlarının kıș mevsimi yağışları üzerinde önemli bir etkisi olduğunu göstermektedir. Kış mevsimi yağıșlarında 1988-1995 yılları arasında görülen en uzun kurak dönemin, aynı dönemde görülen Ocak yağışlarındaki kuraklıktan kaynaklandığı belirlenmiștir. Bu da ilgili yıllarda Ocak aylarında düşen yağışların mevsim ortalamasının çok altında olduğunu göstermektedir. Çok şiddetli kuraklıklar Aralık ayı için 1972, 2013 ve 2015 yıllarında, Ocak ayı için 1992 yılında, Subat ayı için 1989 ve 2008 yllında ve Kıș mevsiminde 1972, 1992 ve 2008 yllarinda meydana gelmiştir. Kış mevsiminde görülen çok şiddetli kuraklıkların, 1972 ve 1992 yıllarında Ocak ayındaki, 2008 yılında ise Şubat ayındaki kuraklıktan kaynaklandı̆̆ı görülmektedir (Șekil $2,4,6)$. Kış mevsimi ve kış mevsimi aylarının kuraklık sınıflarının görülme sıklıkları açısından birbirleri ile uyumlu olduğu görülmektedir.

İkbahar mevsiminde en uzun kuraklık döneminin 1985-1991 yılları arasında, aylıklarda Mart yağışlarında 1989-1992, Nisan yağışlarında 2004-20011 ve Mayıs yağışlarında 1984-1990 arasında gerçekleștiği belirlenmiştir. Nisan ayları için en uzun kuraklık döneminin İlkbahar mevsimi için bulunan en uzun kuraklık dönemi ile çakışmamasına rağmen Nisan aylarında bu dönem içinde kısa süreli fakat çok şiddetli kuraklıklar meydana gelmiştir. İlkbahar mevsiminde 2005 sonrası yıllarda kuraklığın sulaklığa göre daha etkin olduğu görülmektedir. 2005 sonrası yaşanan kuraklıkların Nisan aylarındaki kuraklıklardan kaynakladığı; bir başka ifade ile 2005 sonrasındaki Nisan aylarında mevsim ortalamasindan daha az miktarda yağışların gözlemlendiği görülmektedir. İlkbahar mevsimi aylarında çok şiddetli kuraklıklar, 1983, 1985, 2003, 2004 yıllarının Mart aylarında, 1964 ve 1989 yıllarının Nisan aylarında, 1962, 1981 ve 1999 yıllarının
Mayıs aylarında görülmüştür. İlkbahar mevsiminde çok şiddetli kuraklıklar 1961, 1987, 1989 ve 1990 yıllarında yaşanmıştır. İlkbahar mevsimindeki 1989 ve 1990 yıllarında yaşanan çok şiddetli kuraklıkların, aylık kuraklıklarından kaynaklandığını ve bu yıllarda ilkbahar mevsiminde havza yağışlarında önemli ölçüde azalmanın olduğu anlaşıllmaktadır (Şekil 2, 6).

Haziran, Temmuz ve Ağustos ayları ile yaz mevsiminin için hesaplanan SYİ indislerinin değişimleri ile karşılaştırıldığında, yaz mevsimi en uzun kuraklık süresinin aylık kuraklıklara göre kısa süreli meydana geldiği görülmektedir. Haziran aylarında tüm kuraklık sınıfları görülmesine rağmen Temmuz aylarında orta (Uşak yağışlarında) ve hafif şiddetli kuraklık sınıfları ve Ağustos aylarında sadece hafif şiddetli kuraklık sınıfları meydana gelmiștir. Ancak bu sinıfların mevsimsel bazdaki görülme sıklıkları incelendiğinde çok şiddetli kuraklık sınıfının İcikler, Kula, Selendi ve Uşak yağışlarında, şiddetli ve orta şiddetli kurak sınıflarının havza yağışlarının hepsinde meydana geldiği görülmektedir. Yaz mevsimi kuraklık sınıflarının oluşmasında Haziran ayı yağışlarının etkisinin olduğu anlaşılmaktadır (Şekil 3, 5, 7). Yaz mevsiminin, en uzun kuraklık dönemleri 1987-1990 ve 2006-2009 yılları arasında yaşanmıştır. Yaz aylarında en uzun kuraklıklar, Haziran için 1995-2005, Temmuz için 2007-2012 ve Ağustos için de 1960-1966 yılları arasında meydana gelmiştir.

Sonbahar mevsimi ile mevsim aylarının en uzun kuraklık periyotları karşılaștırıldığında, Sonbahar mevsimlerinde $1966-1969$ ve $1990-$ 1993 yılları arasında, mevsim ayları olan Eylül aylarında 1991-1994, Ekim aylarında 19641969, Kasım aylarında 2010-2013 yılları arasında meydana gelmiştir. Sonbahar mevsimi 1966-1969 yılları boyunca süren kuraklı̆̆ın özellikle Ekim ve Kasım ayları yağışlarından etkilendiği ve bu periyottaki Eylül aylarının ise sulak dönem geçirdiği görülmektedir. Sonbahar mevsiminde 1990-1993 arası süren kuraklığın ise tüm mevsim aylarında da aynı periyot içinde kurak dönem olarak geçtiği görülmüştür. Çok şiddetli kuraklık sınıfı sadece Kasım ayları kuraklıklarında 2011 yılında meydana gelmiş Eylül ve Ekim aylarında hiç görülmemiștir. Sonbahar mevsiminde görülen çok şiddetli kuraklık sınıfı da Kasım aylarında olduğu gibi 2011 yılında meydana gelmiștir. Sonuç olarak diğer aylarda çok şiddetli kurak dönem yaşanmadığından, Kasım ayı yağışlarının 
DEU FMD 21(62), 509-523, 2019

mevsimsel kuraklık üzerinde daha etkili olduğu anlaşılmaktadır (Şekil 6).

1960-2017 yılları arasında Yukarı Gediz Havzası'nda meydana gelen mevsimsel ve yıllık kurakların beraber değerlendirilmesiyle; yıllık kuraklıkların oluşmasında kış mevsimi kuraklıklarının etkisinin oldukça fazla olduğu anlaşılmaktadır. Gerek yıllık kuraklıklarda gerekse kış mevsimi kuraklıklarında 1962-1970 yılları arasında kuraklığın oluşmadığı; havzada yaşanan 1961 yllı kuraklığının ilkbahar mevsimi yağıșlarından kaynaklandığı anlașılmaktadır. Havzada 1987-1995 yılları arasında süren kuraklığın ilkbahar, yaz ve sonbahar mevsimleri sulak olmasına rağmen kış mevsiminin bu periyotta kurak olmasından kaynakladığı anlaşılmaktadır. Havzada özellikle 1984 yılı sonrasındaki periyotlarda yıllık kuraklığın daha sık ve uzun süreli meydana geldiği, yaz ve sonbahar mevsimlerinde bu kuraklıkların etkisinin çok görülmediği anlaşılmaktadır (Şekil 6 , 8). Çok șiddetli kuraklık sınıfının mevsimsel kuraklıklarin hemen hemen hepsinde gözlenmesine karşın, yıllık kuraklıklarda sadece Gediz ve Uşak yağışlarında meydana geldiği görülmektedir (Şekil 7, 9).

Yukarıda değinilen tüm bu irdelemelerin ışığı altında;

- $\quad$ kıș mevsimi yağıșlarında 1972, 1992 ve 2008 yıllarında çok şiddetli kuraklıklarının yaşandığı ve bunların yıllık kuraklıklar içinde önemli bir yer tuttuğu;

- mevsimsel kuraklıklarda en sık kuraklığın kış mevsiminde görüldüğü ve mevsimsel en uzun kuraklığın 8 yll boyunca devam ettiği;

- kış mevsimi kuraklarında Aralık ayı yağışlarının belirleyici olduğu;

- yillık kuraklıklarda en uzun kuraklık döneminin 12 yıl sürdüğü;

- 1984 ve öncesi yllarda sulak dönemlerin daha hakim olduğu fakat sonrası yıllara kuraklığın daha sık, daha șiddetli ve daha uzun süreli gerçekleștiği sonuçlarına ulaşılmıștır.

Sonuç olarak Yukarı Gediz Havzası yağışlarında orta ve üstü şiddette kuraklıklar aylık, mevsimlik ve yıllık dönemlerde ve günümüze doğru siklı̆̆ artarak görülmeye devam etmektedir. Yukarı Gediz Havzası yağışları, havzada yer alan ve Demirköprü Barajı'nı besleyen
Gediz Nehri'nin Acısu, Selendi, Deliiniș ve Demirci kollarının ana su kaynağıdır. Havza yağışlarında meydana gelen kuraklıklar, akım miktarlarını önemli ölçüde etkilemekte ve Demirköprü Barajı'nın su teminini önemli ölçüde azaltmaktadır. Bu nedenle baraj mansabında yeterli sulama suyu sağlanamadığı için hâlihazırda yaşanan tarımsal kuraklıkların gelecekte daha sık ve daha şiddetli biçimde meydana gelmesi kaçınılmazdır. Bu sonuç, havzanın kuraklık eylem planlarının gerekliliğini ve aciliyetini ön plana taşımaktadır.

\section{Kaynakça}

[1] Trenberth, K.E., Dai, A., van der Schrier, G., et al., 2014. Global warming and changes in drought. Nat. Clim. Chang. 4, 17-22.

[2] Shah R, Bharadiya N, Manekar V. 2015. Drought Index Computation Using Standardized Precipitation İndex (SPI) Method For Surat District, Gujarat. Aquat. Procedia 4: 1243-1249. Trenberth, K.E., Dai, A., van der Schrier, G., et al., 2014. Global warming and changes in drought. Nat. Clim. Chang. 4, 17-22.

[3] Liu, Y., Zhu, Y., Ren, L., Yong, B., Singh, V.P., Yuan, F., Jiang, S., Xiaoli, Y., 2019. On The Mechanisims Of Two Component Methods For Construction of Multivariate Drought İndices. Scinece of the Total Environment, 647, 981-991.

[4] Hayes, M., Svoboda, M., Wall, N., and M. Widhalm, 2011. The Lincoln Declaration on Drought: Universal Meteorological Drought İndex Recommended. Bull. Amer. Meteor. Soc., 92, 485-488.

[5] R. Nagarajan, 2009. "Drought indices," in Drought Assessment. Springer, Dordrecht, The Netherlands, 160-204

[6] Slahnia, N., Alizadeh, A., Sanaeinejad, H., Bannayan, M., Zarrin, A., Hoogenboom, G., 2017. Estimation of Meteorological Drought Indices Based on AgMERRA Precipitation Data and Station-Observed Precipitation Data. J. Arid Land, 9(6), 797-809.

[7] Montaseri, M., Amirataee, B. 2017. Comprehensive Stochastic Assessment of Meteorological Drought Indices. International Journal of Climatology, 37, 998-1013.

[8] Arslan, O., Bilgil, A., Veske, O., 2016. Standart Yağıș İndisi Yöntemi İle Kızılırmak Havzası'nın Meteorolojik Kuraklık Analizi. Niğde Üniversitesi Mühendislik Bilimleri Dergisi, 5(2), 188-194.

[9] Doğan, S., Berktay, A., Singh, V.P., 2012. Comprasion of Multi-Monthly Rainfall Based Drought Severity Indices with Application of Semi-Arid Konya Closed Basin, Turkey. Journal of Hydrology, 470-471, 255268.

[10] Labedzki, L., Bak, B. 2014. Meteorological and Agricultural Drought Indices Used in Monitoring in Poland: A Review. Meteorologhy, Hydrology Water Management, 2(2), 3-13.

[11] Ma'rufah, U., Hidayat, R., Prasasti, I., 2017. Analysis of Relationship between Meteorological and Agricultural Drought Using Standart Precipitation Index and Vegatation Index. IOP Conference Series: 
Earth and Enviromental Science, 54, 1-7. DOI:10.1088/1755-1315/54/1/012008

[12] Mondol, A. H., Ara, I., Chandra Das, S., 2017. Meteorological Drought Index Mapping in Bangladesh Using Standardized Precipitation Index Durüng 1981-2010. Advances in Meteorology, 1-17, DOI: $10.1155 / 2017 / 4642060$

[13] Sirdaș, S., Şen, Z., 2003. Meteorolojik Kuraklık Modellemesi ve Türkiye Uygulaması. İTÜ Mühendislik Dergisi, 2(2), 95-103.

[14] Ilgar, R., 2010. Çanakkale'de Kuraklık Durumu ve Eğilimlerinin Standartlaștırılmıș Yağış İndeksi ile Belirlenmesi. Marmara Coğrafya Dergisi, 22, 183204.

[15] Oğuztürk, G., Yıldız, O., 2014. Kırıkkale İli'nde Farkl Zaman Periyotları İçin Kuraklı Analizi. International Journal of Engineering Research and A Development, 6 (2),1-7.

[16] Gümüş, V., Algin, H. M., 2017. Meteorological and Hydrological Drought Analysis of Seyhan-Ceyahn River Basin, Turkey. Meteorological Applications, 24, 62-73.

[17] McKee, T.B., Doesken, N. J., Kleist, J., 1993. The Relationship of Drought Frequency and Duration to Time Scales. Eighth Conference on Applied Climatology. Anaheim, California. No. 1 p. 179-184.

[18] Wu H, Hayes MJ, Wilhite DA, Svoboda MD. 2005. The Effect of The Length of Record on The Standardized Precipitation İndex Calculation. Int. J. Climatol. 25: 505-520. 